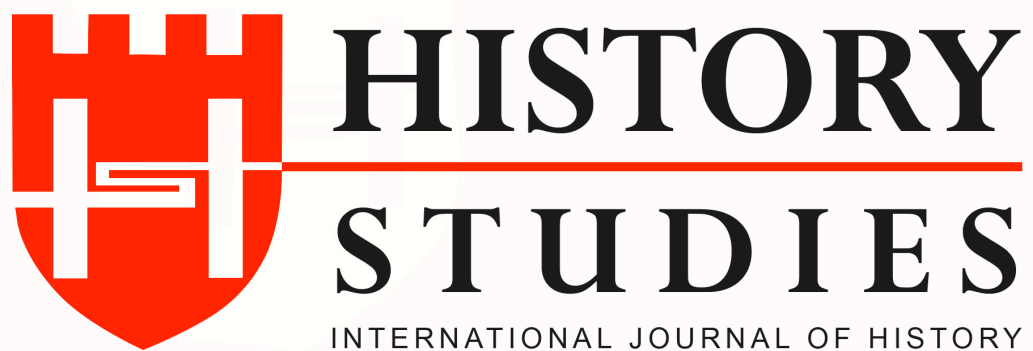

ISSN: 13094173 (Online) 1309 - 4688 (Print)

Volume 12 Issue 1, February 2020

DOI Number: 10.9737/hist.2020.830

Araştırma Makalesi

Makalenin Geliş Tarihi: 29.09.2019 Kabul Tarihi: 06.01.2020

Atıf Künyesi: Ömer Tokuş, "Fâtımîlerin İkircikli Müttefikleri Cerrâhîlerin Filistin ve Çevresindeki

Faaliyetleri", History Studies, 12/1, Şubat 2020, s. 285-297.

\title{
Fâtımîlerin İkircikli Müttefikleri Cerrâhîlerin Filistin ve Çevresindeki Faaliyetleri
}

\author{
Activities of Djarrahids, Hesitant Allies of the Fatimids, in Palestine and Its \\ Surroundings
}

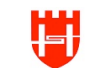

HISTORY

ST UDIES

Volume 12

Issue 1

February 2020

\author{
Dr. Ömer Tokuș \\ ORCID No: 0000-0001-9788-8920 \\ Bingöl Üniversitesi
}

$\ddot{O} \mathbf{z}$

Hulefâ-yi Râşidîn döneminde Müslümanlar tarafından gerçekleşen fetihlerden sonra çok sayıda Arap Kabilesi iskân amacıyla Suriye ve el-Cezîre topraklarına göç etmiştir. Bu şekilde Suriye'ye yerleşen kabilelerden biri olan Tayy Kabilesi, X. ve XI. asırlarda güçlendikten sonra Biladu'ş-Şâm'da cereyan eden siyasî-askerî olayların önemli aktörlerinden biri olmuștur. X. asırda Musul ve Halep'e hâkim olan Hamdânîlere vergi ödeyerek bağlılığını arz eden Tayy Kabilesi, onuncu asrın sonlarına doğru Hamdânîlerin zayıflaması ile birlikte bağımsız bir şekilde hareket etmeye başlamıștır. Hamdânîlerin zaafından istifade eden Ukayl, Numeyr, Kilâb, Kelb ve Tayy gibi kabileler, ele geçirdikleri şehirlerde bağımsız birer siyasî oluşum vücuda getirmişlerdir. Mezkûr kabileler bağımsız bir emirlik oluştururken Tay Kabilesi hâkim olduğu Filistin topraklarında ortaya çıkan Fâtımî baskısından dolayı tam olarak bağımsız bir idarî yapı oluşturmaya muvaffak olamamıştır. Fâtımîlerin 357'de (968) Bilâdu'ş-Şâm'a doğru ilerleyişi esnasında, Tayy Kabilesinin bir kolu olan Cerrâhîler Remle merkez olmak üzere stratejik bir güç olarak sahneye çıkmışlardır. Öncelikle Fâtımîlere karşı Karmatîlerin yanında saf tutan Cerrâhîler, Karmatîlerin Kahire önlerinde mağlup olmaları üzerine müttefiklerinin mallarını yağmalamaktan geri durmamışlardır. Bu sırada Cerrâhî lideri olarak Dağfel ve el-Müferrec adında iki şahsın tarih sahnesine çıktıkları görülmektedir. Cerrâhîler aynı anda birden fazla lider tarafından yönetilmiş ve Fâtımîler ile münasebetleri de tamamen çıkarlara dayalı olmuştur. Buna paralel olarak 400 yılından sonra yeni bir Şiî halife tayin etme girişiminde bulunmuşlardır. Bu çalışmada bir asra yakın bir zaman zarfında Filistin ve çevresinde etkin bir kuvvet olarak varlığını idame ettiren Cerrâhîlerin, Fâtımîler ile münasebetlerinin mahiyeti, tarihi süreci ve Biladü'ş-Şâm’a komşu güçler ile münasebetlerde etkileri ortaya konulmaya çalışılmıştır.

Anahtar Kelimeler: Bilâdü'ş-Şâm, Remle, Tayy Kabilesi, Cerrâhîler, Fâtımîler

Abstract: After the conquests carried out by Muslims during the reign of Rashid Chalips, many Arab tribes migrated to Syria and al-Djazira for resettlement. Tayy tribe, one of the tribes that settled in Syria in this way, became one of the important actors of the political-military events that took place in Bilad al-Sham after gained power in X. and XI. centuries. Tayy tribe, which shows its allegiance to the Hamdanids who dominated Mosul and Aleppo in the X. century by paying taxes, began to act independently towards the end of the tenth century with the weakening of the Hamdanids. Taking advantage of the weakness of the Hamdanids, tribes such as Uqayl, Numayr, Kilab, Kelb and Tayy created independent political formations in the cities they conquered. While the mentioned tribes formed an independent emirate, Tayy tribe was unable to establish a fully independent administrative structure due to the Fatimid repression that emerged in the Palestinian territories they dominated. 
During the advance of the Fatimids to Bilad al-Sham in 357 (968), Djarrahids who are a branch of Tayy tribe emerged on the scene in some cities, mainly Ramla, as a strategic power. Djarrahids, who primarily sided with the Karmatians against the Fatimids, did not hold back from plundering the goods of their allies upon the defeat of the Karmatians in front of Cairo. At this time, two individuals named Daghfal and al-Mufarradj, as Djarrahids leaders, appeared on the stage of history. Djarrahids were ruled by more than one leader at the same time, and their relations with the Fatimids were based entirely on interests. In parallel, after 400 years, they attempted to appoint a new Shiite caliph. In this study, it was tried to reveal the nature and historical process of the relations of the Djarrahids, who had survived as an effective force in Palestine and its surroundings for a century, and their influence in relations with forces adjacent to Bilad as-Sham was tried to be demonstrated.

Keywords: Bilad al-Sham, Ramla, Tayy Tribe, Djarrahids, Fatimids

\section{Giriş}

Cerrâhîlerin (Benü’l-Cerrâh) intisap ettikleri Benî Tayy, Kahtânî (Güney Arapları/Yemenî) Araplarının bir batnı olup Arabistan'da Ecâ (أجأ) ve Selma (سلمى) dağları1 arasında bulunan yurtlarını miladi III. yüzyıldan itibaren terk ederek önceleri Haleb ve çevresine daha sonraları ise Belkâ, Havran ve Dımaşk'a göç etmiştir ${ }^{2}$. Cerrâhîlerin tarih sahnesine çıkan ilk liderleri, Bilâdü'ş-Şâm'a yönelen Fâtımîlere karşı Karmatîler ile ittifak kuran Dağfel b. el-Cerrâh ve Hassân b. el-Cerrâh ${ }^{3}$ Benî Tayy'a mensupturlar. Benî Tayy, Hicri IV. yüzyılda (Miladi X. Asır) Ukayl, Numeyr, Kilâb ve Kelb ile birlikte Hamdânîlerin Halep hâkimiyeti döneminde vergi vermek suretiyle Hamdânîlere tabiiyetlerini arz etmişlerdir ${ }^{4}$. Hamdânîlerin inkırazı ile birlikte Ukayl Kabilesi Musul ve çevresinde, Numeyr Kabilesi Harran, Rakka ve Serûc'ta, Kelb kabilesi Dımaşk'ta, Kilâb Kabilesi de Halep şehrinde idareyi ele geçirerek müstakil birer emirlik tesis etmiştir. Söz konusu kabileler ile birlikte Hamdânî tebaasını oluşturan Benî Tayy ise müstakil bir emirlik kuramadığı gibi Fâtımîlerin Bilâdü'ş-Şam hâkimiyetinin önündeki en büyük engellerden biri olmuş ve bölgedeki hac kafileleri için de bir tehdit olarak temayüz etmiştir ${ }^{5}$.

\section{Cerrâhîlerin Ortaya Çıkışı ve Faaliyetleri}

Fâtımîler 358'de (969) Mısır'ı ele geçirdikten sonra doğu ve kuzey yönünde ilerlemeye başlayarak Suriye'deki dâhilî gelişmelere müdahil olmuşlardır. Bu faaliyetler çerçevesinde Fâtımî komutanı Cevher es-Sıkıllî, 358'de (969) Ca'fer b. Fellâh el-Kutâmî'yi Bilâdu'ş-Şâm'a sevk etmiştir. İhşidîlerin Bilâdü'ş-Şâm'daki bakiyelerini hedef alan bu Fâtımî kuvvetleri, Karmatîlerin $^{6}$ İhşidîlerden almakta oldukları yıllık 300 bin dinar nedeniyle Karmâtîler ile karşı karşıya gelmişlerdir? ${ }^{7}$ Filistin ve çevresinde özellikle de Gazze ve el-Halîl gibi şehirlere

\footnotetext{
${ }^{1}$ Ecâ ve Selmâ Tayy kabilesinin yurdu olarak bilinmekte olup Tayy dağları yani Cebel-i Tayy olarak adlandırılmıştır bkz. Yâkût el-Hamevî, Mu'cemu'l-Buldân, I, Beyrut 2010, s. 94-98.

${ }^{2}$ Marius Canard, "Djarrahids", The Encyclopaedia of Islam (EI), II, Leiden 1991, s. 482; Muhammed Abdulkadir Hureysât, "Cerrâhîler”, DIA , c. VII, s. 415; Âdem Apak, "Tay (Benî Tay)", DİA, c. XL, İstanbul 2011, s. 187.

3 İbnü'l-Adîm, Benî el-Cerrâh'ın en önemli simalarından biri olan Hassân b. el-Müferric'in soy şeceresini "Hassân b. el-Müferric b. Dağfil b. el-Cerrâh b. Şebîb b. Mes'ûd b. Es'ad b. Muzer b. Sâlim b. Sa'd b. Semî' b. Hût b. Ma'bed $b$. Is $a$ b. Eflet $b$. Silsele $b$. Amr b. Silsele b. Ganem b. Sevr b. Ma'n et-Tầ’” şekilde vermektedir bkz. İbnü'lAdîm, Buğyetu't-taleb fi tarihi Haleb, c. V, thk. Süheyl Zekkâr, Beyrut ts., s. 2239.

${ }^{4}$ Mustafa Ali Mustafa el-Hiyârî, el-İmâretü't-Tâ'iyye fî̀ Bilâdi'ş-Şâm fî'l-karneyn es-sâlis aşer ve'r-râbî' aşer elmilâdeyn, Beyrut 1969, s. 52.

5 Muhammed Süheyl Takkûş, Târihu'l-Fâtımiyyin fî Şimâli Ifrikiyye ve Mısır ve Bilâdi'ş-Şâm, Dâru'nNefâ'is,Beyrut 2007, s. 241; Clifford Edmund Bosworth, Doğuştan Günümüze İslâm Devletleri Tarihi, çev. Hande Canl1, İstanbul 2005, s. 111-113,133-136, 140-145.

${ }^{6}$ Karmatîler hakkında bkz. Abdullah Ekinci, Ortadoğu'da Marjinal Bir Hareket: Karmatîler (Ortadoğu'da İlk Sosyalist Yapılanma), Ankara 2005.

7 el-Azîmî, Tarihu Haleb, thk. İbrahim Za'rûr, Dımaşk 1984, s. 304; Sibt İbnü'l-Cevzî, Mirât'z-Zamân fí Tarîhi'l'Ayân, c. XI, thk. Kamil Selman el-Cebûrî, Dâru'l-Kutubi'l-İlmiyye, Beyrut 2013, s. 225-227; Makrîzî, Ittti'azü’l-
} 
yerleşen Cerrâhîlerin mensup olduğu Benî Tayy da Fâtımî-Karmatî güçlerinin Bilâdu'ş-Şâm üzerindeki rekabetlerinde, Karmatîlerin saflarında yer alarak tarih sahnesine çıkmışlardır ${ }^{8}$. Fâtımîlerin 359'da (970) Dımaşk'1 işgal etmelerinden sonra el-Hasan (el-A'sam) b. Ahmed liderliğindeki Karmatîler, Abbâsîlerden aldıkları destekle Fâtımî komutanı Ca'fer b. Fellâh'ın üzerine yürümüşlerdir'. Şiî Karmatîler ile Sünni Abbâsîlerin Fâtımîlere karşı bir araya gelmelerinin sebebi; Karmatîlerin İhșidîlerden almakta oldukları 300 bin dinarlık geliri kaybetmeleri ve Abbâsîlerin de Şiî Fâtımîlerin Bilâdü'ş-Şâm'a ilerlemelerini önlemek istemeleri idi. Ayrıca bu mücadelelerin nihayetinde iki Şî̂ gücün de bu çekişmeden zayıflayarak çıkmaları Abbâsîlerin çıkarlarına hizmet edecekti.

Karmatî el-Hasan b. Ahmed, Abbâsîlerden aldığı destekle Zilkade 360'ta (Ağustos-Eylül 971) Dımaşk önlerine gelerek hezimete uğrattığı Fâtımî komutanı Ca'fer'i öldürüp kenti zapt etmiştir. Karmatîler Dımaşk'ı aldıktan sonra yaptıkları anlaşma doğrultusunda şehirde Abbâsîler adına hutbe okutmuşlardır ${ }^{10}$. Mezkûr başarıdan sonra Mısır'a yönelen el-Hasan yolu üzerinde hâkimiyet altına aldığı Remle'ye de İhşidîyye, Kafûriyye ve Cerrâhîlerden Dağfel b. el-Cerrâh et-Taî'yi bırakmıştır ${ }^{11}$. Cerrâhîlerden tarih sahnesine çıkan ve kaynaklarda adına tesadüf edebildiğimiz ilk şahsiyet 360'ta (971) Remle'de bırakılan Dağfel b. el-Cerrâh'tır.

Misır'a ilerleyen Karmatîler Ayn Şems'e kadar ulaşmış ve1 Rebiyülevvel 361'de (22 Aralık 971) yenilerek geri çekilmek zorunda kalmışlardır ${ }^{12}$. Karmatîlerin saflarında bulunan Ukayl ve Tayy gibi kabileler de Makrîzî'nin kayıtlarına göre mağlubiyetten istifade etmek suretiyle elHasan'ın mallarını yağmalamışlardır ${ }^{13}$. Bu eyleme Cerrâhî lideri Dağfel'in katılıp katılmadığı tespit edilememekle birlikte Tayy Kabilesinin bu girişimi, hâlihazırda bu dönemde bedevi Araplar tarafından icra edilen mutat davranışlardan biri idi.

Karmatîler 363'te (974) tekrar Kahire önlerine geldiklerinde Hassân b. el-Cerrâh da onlar ile aynı safta yer almıştır. Hassân, Karmatî ordusunda bulunmasına rağmen Fâtımîler'in maddi vaatleri karşısında Karmatîlere ihanet ederek geri çekilmiştir. Kendisine verilen 100 bin dinarı alan Hassân, Karmatî lideri el-Hasan'ı savaş meydanında yalnız bırakmıştır. Ancak Fâtımîler, Cerrâhîlere teklif ettikleri meblağı çok bulmuş ve paraların bulunduğu kesenin üstüne altın sikkeler alt tarafına ise altın suyuna bastırılmış sahte bakır sikkeler koyarak Hassân'1 aldatmışlardır. Hilenin farkına varmayan Hassân aldığı paralar ile savaș meydanını terk ederken Kartmatîler de Fatımîler tarafından dağıtılmışlardır ${ }^{14}$. Yukarıda 361 (971) ve 363 (974) yılı olaylarında Cerrâhîlerden iki farklı şahsiyetin adının geçmesi Dağfel ve Hassân'ın aynı kişi olabileceğine dair görüşler serdedilmesine neden olmuştur ${ }^{15}$. Ancak 361'de (971) Karmatîler ile eşgüdümlü hareket eden Dağfel ile 363'te (974) aynı şekilde Karmatîlerin safında yer alan

hünefâ bi-ahbâri'l-e'immeti'l-Fâtımîyyin el-Hulefâ, c. I, thk. Muhammed Abdulkadir Ahmed Ata, Beyrut 2001: s. 188-192, 242; el-Hıyârî, age, s. 55

8 Şerif Emîn Muhammed Ebû Şemâle, Filistîn Tahte'l-Hükmi'l-Abbâsî el-Mübâşsir (h. 132-264/750-878), (elCâmi'atu'l-İslâmiyye), Gazze 2011, s. 106.

9 el-Antâkî, Tarihu'l-Antâkî, thk. Ömer Abdusselam Tedmürî, Trablus 1990, s. 143-146; İbnü'l-Kalânisî, Zeylü Târîhi Dımaşk, thk. H. F. Amedroz Beyrut 1908, s. 1-2; Sibt İbnü'l-Cevzî, age, XI, s. 225-227; Makrîzî, age, I, 2001: s. 242-243.

10 el-Antâkî, age, s. 147; Makrîzî, age, I, s. 197-198, 242-243; Nihat Yazılıtaş, Fâtımî Devleti Tarihi, İstanbul 2010, s. 88.

${ }_{11}$ İbnü'l-Kalânisî, age, s. 1-2; Sibt İbnü'l-Cevzî, age, XI, s. 225-227; Mustafa Murad ed-Debbâğ, Bilâdunâ Filistîn, c. 4/2. K1sim, Kefer Kara' 1991, s. 389-390.

12 el-Antâkî, age, s. 146-147; Sibt İbnü'l-Cevzî, age, XI, s. 226-227; Makrîzî, age, I, s. 242-243.

${ }^{13}$ Makrîzî, age, I, s. 199-200.

14 İbnü'l-Kalânisî, age, s. 3; el-Antâkî, age, s. 152; İbnü'l-Esîr, el-Kâmil fî̀t-Tarih, c. VIII, çev. Ahmet Ağırakça, İstanbul 1991, s. 547-548; Makrîzî, age, I, s. 260; Muhammed Kürd Ali, Hittatu'ş-Şâm, c. I, Kahire 2007, s. 222; Hureysât, age, s. 415; Takkûş, age, s. 241; Nihat Yazılıtaş, Fâtımî Devleti'nde Türkler, Ankara 2009, s. 58.

${ }^{15}$ Canard, age, s. 482. 
Hassân'ın aynı kişi olabileceklerine yönelik somut bir delil bulunmamaktadır. Kayıtlardan da anlaşılacağı gibi her iki olayı nakleden tarihçilerin verdikleri bilgiler Cerrâhî ailesinden iki ayrı şahsiyetin mevcudiyetine delalet etmektedir.

Bağdat'ta yaşanan çekişmelerden kaçarak 364'te (974) Dımaşk çevresine gelen Türk asıllı Alptekin et-Türkî, Fâtımîlere karșı güçlü bir rakip olduğundan konjonktüre göre hareket eden Hassân da öncelikle 366'da (976-977) Alptekin ve Karmatîlerin oluşturduğu ittifak bloğunda yer alarak Fâtımî komutanı Cevher es-Sıkıllî ile savaşmış, ardından da halifenin daveti ile Kahire'ye giderek Fatımîlere tabiiyetini bildirmiștir ${ }^{16}$. Cerrâhîlerden Hassân ve Dağfel ile birlikte adına tesadüf edilen şahsiyetlerden biri de el-Müferrec b. Dağfel'dir. Fâtımîler ile yaptığ1 mücadeleyi Muharrem 368'de (Ağustos 978) Tavvâhin Nehri kıyısındaki savaş ile kaybeden Alptekin, savaş meydanından kaçarken Cerrâhîlerden el-Müferrec b. Dağfel tarafından esir alınarak Fâtımî halifesi el-Azîz'e gönderilmiştir ${ }^{17}$.

368 (978) yılından sonraki olaylar hakkında nakledilen kayıtlar Cerrâhî ailesinin liderliği hususunda muhtelit bilgiler içermektedir. İbn Miskeveyh ve İbnü'l-Esîr gibi tarihçiler 368 (978) yılı olaylarını naklederken Dağfel b. Müferrec b. el-Cerrâh'ın Remle ve çevresine hâkim olduğunu kaydetmektedirler ${ }^{18}$. Buna karşın el-Antâkî ve Makrîzî de mezkûr şehir ve bölgenin Müferrec b. Dağfel b. Cerrâh'ın hâkimiyeti altında olduğunu yazmaktadırlar ${ }^{19}$. Bu kayıtlar yorumlandığında 366'da (976-977) Hassân'in, 368'de (978) ise el-Müferrec ve Dağfel'in adlarının öne çıkması Cerrâhîlerde müşterek bir liderlik anlayışının hâkim olduğu izlenimini vermektedir.

Büveyhîlerin icra ettikleri saldırılar sonucunda 368'de (978) Musul'u terk eden Hamdânî Emîri Ebu Tağlib Gazanfer ${ }^{20}$ Dımaşk önlerine geldiğinde, şehrin valisi Kassâm Mısır'dan yardım istemek zorunda kalmıştır. Bunun üzerine Fâtımî halifesi el-Azîz, el-Fazl adlı komutanını Dımaşk'a yönlendirdiğinde yol üzerinde Remle'ye uğrayan el-Fazl, Cerrâhî lideri el-Müferrec ile Ebu Tağlib'e karşı anlaşma yapmıştır. Böylece şehrin yönetimini el-Müferrec'e bırakan el-Fazl buradan kuzeye doğru ilerlemiştir. Bu sırada Bilâdü'ş-Şâm'da Benî Ukayl ile Cerrâhîler arasında bazı anlaşmazlıklar yaşandığından Hamdânî Emîri Ebu Tağlib, Fâtımîlerin desteklediği Cerrâhîlere karşı Benî Ukayl ile ittifak kurmuştur. İki taraf arasındaki husumet 1 Safer 369'da (28 Ağustos 979) Remle önlerinde bir çatışmaya dönüşmüştür. Savaş öncesinde Benî Ukayl karşı tarafın niceliksel durumunu görünce Ebu Tağlib'i yalnız bırakarak savaş meydanından uzaklaşmıştır. Bundan dolayı az sayıdaki adamıyla savaşmak zorunda kalan Ebu Tağlib ise mağlup ve esir edilmiştir. Ardından da Cerrâhî lideri el-Müferrec tarafından öldürülen Ebu Tağlib'in kesik başı da Mısır'a gönderilmiştir ${ }^{21}$.

\footnotetext{
16 İbn Kalânisî, age, s. 11-21; İbnü'l-Esîr, age, VIII, s. 564-570; Makrîzî, age, I, s. 286; Aydın Çelik, "Fatımîler Devletinde Bir Türk Komutan: Alptekin”, Firat Üniversitesi Sosyal Bilimler Dergisi, c. 12, sayı 1, Elazı̆ 2002, s. 283-296.

17 İbn Miskeveyh, Tecâribü'l-Ümem ve Te'akubi'l-Himem, c. VI, thk. Ebu'l-Kâsım İmâmî, Tahran 2000, s. 434 Türkçe trc. İbn Miskeveyh, Tecâribü'l-Ümem, trc. Kıvameddin Burslan, TTK, Ankara 2016, s. 765-766; el-Antâkî, age, s. 179-181; Hureysât, age, s. 415; Yazılıtaş, Fâtımî Devleti’nde Türkler, s. 67-74; Bunlardan farklı olarak Makrîzî, (age, I, s. 287-289) Fâtımî halifesi el-Azîz'in öncü birliklerinin başında Hassân b. Ali b. Müferrec'in bulunduğunu, mağlup olarak savaş meydanını terk eden Alptekin'in de Hassân'a sı̆̆ındığını ve Hassân'ın da Alptekin'i Mısır'a gönderdiğini nakletmiştir. Bu bilgilere Fâtımîlerin Hassân'a beş at ve beş yük mal vererek ödüllendirdiğini de eklemektedir.

${ }_{18}^{1}$ İbn Miskeveyh, age, VI, s. 450-452; İbnü'l-Esîr, age, VIII, s. 604-605.

19 el-Antâkî, age, s. 192; Makrîzî, age, I, s. 2001, 291.

${ }^{20}$ İbn Miskeveyh, age, VI, s. 450-452; Türkçe trc. s. 782-783; İbn Kalânisî, age, s. 21-22; İbnü’l-Esîr, age, VIII, s. 604-605.

${ }^{21}$ İbn Miskeveyh, age, VI, 451-453; Türkçe trc. s. 783-784; İbnü'l-Kalânisî, age, s. 21-25; el-Antâkî, age, s. 192; İbnü'l-Esîr, age, VIII, s. 604-605; IX, 1991, s. 16; Ali b. Zâfir el-Ezdî, Ahâru'd-devleti'l-Hamdâniyye bi'l-Mevsıl
} 
Hamdânî Emîri Ebu Tağlib'in öldürülmesinden sonra Cerrâhîler Filistin ve çevresinde güçlenmiş ve buna paralel olarak da halk üzerindeki baskılarını da artırmışlardır. Bunun üzerine Fâtımîler, sükûneti tesis etmek ve Cerrâhîlerin sebep olduğu kaosu sonlandırmak için Beltekin et-Türkî'yi ${ }^{22}$ Remle'ye göndermişlerdir. Taraflar Remle yakınlarında karşılaştıklarında Beltekîn arkadan dolanarak ani bir baskın ile İbnü'l-Cerrâh'1 yenerek tutsak etmiştir. Daha sonra bir yolunu bularak kurtulmayı başaran İbnü'l-Cerrâh önce Humus'a ardından da Antakya'da mukim Bizans valisine iltica etmiştir. Ancak Bizans kuvvetleri büyük bir ordu ile İslâm topraklarına doğru ilerleyince de İbnü'l-Cerrâh Humus hâkimi Bekcûr'u

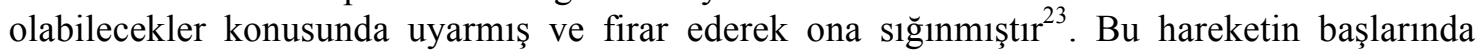
Bizans birlikleri Halep önlerine ulaştıklarında İbnü'l-Cerrâh da Bizans saflarında bulunuyordu ${ }^{24}$. Şüphesiz İbnü'l-Cerrâh, hareket halindeki Bizans birliklerini terk ederek Humus'a kaçmıştır. Böylece yeniden Bilâdu'ş-Şâm'a dönen İbnü'l-Cerrâh'ın bir süre sonra tekrar Fâtımîlere muhalefet etmeye başladığ 1 görülmektedir. Bu gelişmeler çerçevesinde elAzîz'in 371'de (981-982) görevlendirdiği Reşîk el-Azîzî adlı adamı İbnü'l-Cerrâh'1 hezimete uğratarak çöle çekilmeye zorlamıştır. İbnü'l-Cerrâh, yağma saldırılarını devam ettirdiği için Reşîk el-Azîzî’nin saldırısına maruz kalarak 373'te (983) Humus'a gitmiştir. Ancak Hımıs’ta da tutunamayan İbnü'l-Cerrâh Bizans'tan yardım almak için Antakya'ya ulaşmış ve beklediği ilgiyi göremeyince de ülkesine dönerek el-Azîz'den aman istemiş ve el-Azîz de ona aman vermiştir ${ }^{25}$. Buna rağmen 378'de (988-989) Fâtımî komutanı Münîr el-Hâdim'in Dımaşk havalisinde bulunan İbnü'l-Cerrâh'1 cezalandırmak amacıyla gönderilmesi Fâtımîlerin İbnü'lCerrâh'a güvenmediklerini göstermektedir. Münîr el-Hâdim'in akınlarından dolayı İbnü'lCerrâh tutunamayarak müttefiki Humus emîri Bekcûr ile birlikte Rakka'ya gitmek zorunda kalmıştır ${ }^{26}$.

İbnü'l-Cerrâh'ın 379'da (989-990) Sumeyrâ ve Feyd arasında, hac kafilesine saldırarak 300 bin dirhem değerinde elbise ve malları gasp etmesi Fâtımîlerin İbnü'l-Cerrâh'a güvenmemelerinin sebebini açıklığa kavuşturmaktadır ${ }^{27}$. Buna rağmen menfaatler, taraflar arasındaki ilişkileri de zaman ve şartlara göre değiştirebilmiştir. Münîr el-Hâdim'in Abbâsîler ile yazıştığına dair 381'de (991) varit olan haberlerden dolayı Fâtımîler, İbnü'l-Cerrâh'a bölgeye gönderdikleri Mencûtekîn ile birlikte hareket etmesi için hilat vermişlerdir ${ }^{28}$. Fâtımî veziri Ya'kûb b. Killis Zilhicce 380'de (Şubat-Mart 991) vefat etmeden önce halifeye "Seninle aranı bozmadıkları sürece Bizans ile ilişkilerini iyi tut. Hamdânîleri davet ve para ile hoşnut tut. Eline firsat geçtiğinde el-Müferrec b. Dağfel'e acıma" diyerek vasiyette bulunmuştur ${ }^{29}$. Anlaşılacağ1 üzere Cerrâhîlerin tutarsız ve ikircikli politikası Fâtmîler cihetinde onlara karşı büyük bir güvensizliğe neden olmuştur. Bununla birlikte Şam diyarına yapılan saldırılarda Fâtımîler, Cerrâhîlerden yardım istemeyi de ihmal etmemişlerdir. 385 'te (995) Bizans birliklerinin Şam diyarına ulaştığına dair Mısır'a gelen haberler üzerine halife el-Azîz, İbnü'l-

ve Haleb ve Diyâr-ı Bekr ve's-Suğûr, thk. Temîme er-Ravvâf, Beyrut 1985, s. 46; Makrîzî, age, I, s. 291-294; Takkûş, age, s. 241-242; Yazllıtaş, Fâtımî Devleti Tarihi, s. 113-114.

${ }^{22}$ İbn Kalânisî, age, s. 25; İbnü'l-Esîr, age, IX, s. 16; Bu ismin farklı yazımları için bkz. Yazılıtaş, Fâtımî Devleti'nde Türkler, s. 75.

${ }^{23}$ İbn Kalânisî, age, s. 25, 30-31; el-Antâkî, age, s. 200-201; İbnü’l-Esîr, age, IX, 1991, s. 16, 53-54; Makrîzî, age, I, s. 296-297.

${ }_{24}$ İbn Kalânisî, age, s. 30-31; İbnü'l-Esîr, age, IX, s. 53-54.

${ }^{25}$ el-Antâkî, age, s. 199-200; Takkûş, age, s. 242.

${ }^{26}$ Makrîzî, age, I, s. 298-299.

27 İbnü'l-Cevzî, el-Muntazam fî Tarihi'l-Mülûk ve'l-Ümem, c. XIV, thk. Muhammed Abdulkadir Ata-Mustafa Abdulkadir Ata, Beyrut 2012, s. 337; İbnü'l-Esîr, age, IX, s. 63; Sibt İbnü'l-Cevzî, age, XI, s. 388.

${ }^{28}$ Makrîzî, age, I, s. 303.

${ }^{29}$ İbn Kalânisî, age, s. 32. 
Cerrâh'a Ceyş b. Samsâma komutasında sevk ettiği orduya katılması için 50 bin dinar göndermiştir ${ }^{30}$.

Bilâdü'ş-Şâm'daki gelişmelere kayıtsız kalmayan el-Azîz 386'da (996) bölgeye hareket ederken Büleybis'e ulaştı̆̆gnda vefat etmiştir ${ }^{31}$. Halifenin ölümünden sonra yerine geçen oğlu el-Hâkim'e vasi olarak tayin edilen Bercevân (Ercuvân) Kutâme Kabilesi'nden el-Hasan b. Ammâr ile yaşadığı ihtilaftan dolayı Suriye'de bulunan Mengütekin'den yardım istemişstir. Bu doğrultuda Misır'a ilerleyen Mengütekin ile birlikte hareket edenlerden biri de İbnü'l-Cerrâh (el-Müferrec b. Dağfel) idi. Ancak Mengütekin Misır önlerinde Ebu Temîm Süleyman elKutâmî'nin komutasındaki birlikler ile karşılaştığında İbnü'l-Cerrâh geri çekilmiştir. Bunun üzerine Mengütekin de hezimete uğrayarak ricat edince Süleyman Suriye'ye yürümüş ve Remle'ye ulaştığında tutsak ettiği İbnü'l-Cerrâh'1 Mengütekin ile birlikte Mısır'a yollamıştır. Mısır'a ulaşan İbnü'l-Cerrâh halife tarafından affedilmiş ve hediyelere gark edilmiştir ${ }^{32}$. Buna rağmen çok geçmeden İbnü'l-Cerrâh, Sur şehrini ele geçirerek Fâtımîlere isyan bayrağını açan el-Allâka adında bir şahsın sebep olduğu kargaşadan istifade ederek isyan etmiştir. ElAllâka'nın tenkil edilmesinden sonra Fâtımî komutanı Ceyş b. Samsâma, el-Müferrec b. Dağfel'i yeniden bozguna uğratmıştır. Başarısızlıktan sonra Cebel-i Tayy'a sığınan İbnü'lCerrâh ailenin yaşlı kadınlarını Mısır'a göndererek halifeden aman almaya muvaffak olmuştur ${ }^{33}$.

Daha ziyade yağma ve gasp faaliyetleriyle beslendiği anlaş1lan el-Müferrec, 389' da (998999) bir hac kafilesinin yolunu tevkif ettiği hacıları 9 bin dinar mukabilinde salıvermiştir ${ }^{34}$. Akabinde de Cemaziyülahir 395'te (Mart-Nisan 1005) Berka şehrinde Emevî ailesine mensup olduğunu iddia eden Ebu Rekve lakaplı el-Velîd b. Hişâm adında bir şahsın isyanından dolayı el-Hâkim, el-Müferrec ve oğulları Ali, Mahmud ve Hassân'a bol miktarda erzak ve silah göndererek onlardan destek istemiştir. Bilâdü'ş-Şâm'daki kabilelerin de yardımıyla mezkûr isyan hareketi Zilhicce 396'da (Ağustos-Eylül 1006) Fâtımî komutasnı el-Fazl b. Sâlih tarafından bastırılmıştır. Bu başarılarda payı olduğu anlaşılan Cerrâhîlerin de içinde bulunduğu kabileler Mısır'a giderek Fâtımîlerin armağanlarına nail olmuşlardır ${ }^{35}$. Yağma faaliyetlerinden vazgeçemeyen el-Müferrec 397'de (1006-1007) başka bir hac kafilesine yaptığı baskında kafiledeki insanların hac farizasını eda edemeden ülkelerine dönmelerine sebep olmuştur ${ }^{36}$.

Babası ve kardeşleri 399'da (1008-1009) Fâtımî halifesi el-Hâkim vasıtasıyla öldürülen Ebu'l-Kâsım el-Hüseyin b. el-Mağribî'nin Zilkade 400'de (Haziran-Temmuz 1010) Mısır'1 gizliden terk ederek Remle'de bulunan Cerrâhî emîri Hassân'a sığınması Fâtımî-Cerrâhî münasebetleri açısından dönüm noktasını oluşturmaktadır ${ }^{37}$. Daha önce Fâtımîler ile siyasîaskerî açıdan mücadele eden Cerrâhîler, İbnü'l-Mağribî'nin de kışkırtmaları ile Fâtımîlere karşı Şiî halife tayin etme girişiminde bulunmuşlardır. Fâtımîlerin Halep'e sevk ettiği Yaruktekîn etTürkî de el-Müferrec ve oğlu Hassân tarafından esir alınarak 2 Şevvâl 401'de (9 Mayıs 1011) öldürülmüsşür. Bundan sonra Remle ve çevresini alan baba-oğul, etraflarına topladıkları çok sayıda adamla yağma ve gasp eylemlerini artırınca el-Hâkim gönderdiği mektupla onları tenkit

\footnotetext{
${ }^{30}$ Makrîzî, age, I, s. 316.

${ }^{31}$ İbn Kalânisî, age, s. 44; el-Antâkî, age, s. 235; İbnü’l-Esîr, age, IX, s. 97.

32 İbn Kalânisî, age, s. 46-47; el-Antâkî, age, s. 239; İbnü'l-Esîr, age, IX, s. 97; Mustafa Öz, "Hâkim-Biemrillah", DİA, c. XV, İstanbul 1997, s. 200; Yazılıtaş, Fâtımî Devleti'nde Türkler, s. 95.

33 İbn Kalânisî, age, s. 50-51; İbnü'l-Esîr, age, IX, s. 167; Takkûş, age, s. 289.

34 İbnü'l-Cevzî, age, XV, s. 15; Sibt İbnü'l-Cevzî, age, XI, s. 468.

35 el-Antâkî, age, s. 259, 264-27; Makrîzî, age, I, s. 363-364.

${ }^{36}$ İbnü'l-CevZî, age, XV, s. 55; İbnü'l-Esîr, age, IX, s. 167.

37 el-Azîmî, age, s. 319; Makrîzî, age, I, 2001: s. 375; Öz, age, s. 200; Takkûş, age, s. 290; Halit Özkan, "Vezîr elMağribî” DİA, XLIII, İstanbul 2013, s. 92-94.
} 
ederek azarlamıştır ${ }^{38}$. Ebu'l-Kâsım el-Mağribî’nin teşviki ile bağımsız hareket etmeye başladığı anlaşılan Hassân, el-Hâkim adına okutmakta olduğu hutbeye nihayet vermiştir ${ }^{39}$. ErRûzrâverî'nin kayıtlarından bu sırada el-Müferrec ve oğlu Hassân'ın Remle'de ortak bir yönetim sergiledikleri ve Ebu'l-Kâsım'ın da Hassân'ın üzerinde büyük bir etkiye sahip olduğu anlaşılmaktadır. Yaruktekin'in öldürülmesinden sonra Ebu'l-Kâsım el-Mağribî, el-Müferrec ve evlatları ile görüşüp el-Hâkim ile barış yapmanın artık mümkün olmadığını söyleyerek alternatif bir halife tayin etmeleri hususunda onlara telkinlerde bulunmuştur. $\mathrm{Bu}$ amaçla soyunda herhangi bir tartışmanın bulunmadığını iddia ettiği Mekke emiri Ebi'l-Fütûh Hasan b. Cafer b. Muhammed el-Alevî el-Hasanî adına hutbe okumalarını salık vermiştir. Fâtımîler ile yaşanan problemlerden dolayı çıkış yolu bulamayan el-Müferrec ve Hassân da bu teklifi kabul edip gönderdikleri iki elçi ile Ebi'l-Fütûh'u Filistin'e davet etmişlerdir ${ }^{40}$.

Böylece Remle'ye gelen Ebi'l-Fütûh, Hassân, babası ve Cerrâhîler tarafından büyük bir tören ile karşılanmış ve kendisine 403'te (1012) emirü'l-mü'minin unvanı ile er-Râşid billlah lakabı verilmiştir. Remle'de yaşanan bu gelişmeler Fâtımîler tarafından yakından takip edildiğinden halife el-Hâkim, Hassân, el-Müferrec, Cerrâhîlerin ileri gelenlerine ve elMüferrec'in Ali ve Mahmud adındaki çocuklarına bazı maddi tekliflerde bulunarak onları bu fikirlerinden vazgeçirmeye çalışmıştır. El-Hâkim diğer taraftan da Ebi'l-Fütûh'un Mekke'de bulunan amcasının oğluna haber göndererek şehrin idaresini kendisine vereceğini söylemiştir. Cerrâhîlerin el-Hâkim'in maddi ihsanlarını kabul etmesi üzerine durumu zayıflayan Ebi'lFütûh, el-Hâkim'in teşebbüsü neticesinde Mekke'nin yönetimini de kaybedeceğini anlayınca büyük bir ümitsizliğe kapılmıştır. Müteakiben Hassân'ın annesini halife el-Hâkim'e gönderdiğini öğrenen Ebi'l-Fütûh, Hassân'ın babası el-Müferrec'e sığınarak Mekke'ye dönmesi için yardım etmesini istemiştir. Bunun üzerine Ebi'l-Fütûh'u himayesine alan elMüferrec onu Mekke'ye göndermiştir. Mekke'ye ulaştıktan sonra el-Hâkim'den özür dileyen Ebi'l-Fütûh da affedilerek yeniden Mekke'nin idaresine tayin edilmiştir. Ebi'l-Fütûh hareketinin planlayıcısı olan Ebu'l-Kâsım el-Mağribî de Irak'a gönderilene kadar elMüferrec'in yanında ikamete icbar edilmiştir ${ }^{41}$.

$\mathrm{Bu}$ teşebbüsten kısa bir süre sonra el-Hâkim, Cerrâhîlerin Remle'deki egemenliklerini sonlandırmak veya onları zayıflatmak gayesiyle el-Müferrec'i zehirletmeye karar vermiştir. Bunun için de İbnü'l-Müdebbir adında bir kâtip ile anlașmıștır. İbnü'l-Müdebbir kendisine verilen görevi başarı ile yerine getirip Mısır'a kaçmıştır. Hassân da babasının başına gelenlerden dolayı endişelenerek annesi ile bir cariyesini aman dilemek amacıyla el-Hâkim'e göndermiş ve el-Hâkim'in kız kardeşi ile konuşarak durumlarını anlatmışlardır. Bu görüşmelerden sonra el-Hâkim, Hassân'ın annesine bir yüzük, yün elbiseler ve Hassân'ın binmesi için de bir binek vermiştir. Hassân kendisine takdim edilen binek ile Remle'ye girmiş ve affedilerek Remle'nin idaresine getirilmiştir. Bu anlaşmadan sonra el-Hâkim'in vefatına kadar da Hassân'ın Fâtımî topraklarına saldırmadığı anlaşılmaktadır ${ }^{42}$. El-Antâkî mezkûr tarihten sonra Şâm bölgesinin Cerrâhîlerin hâkimiyetine geçtiğini ve müsaderelerden dolayı Hristiyanların Lazkiyye ve Antakya gibi şehirlere yerleşmek zorunda kaldıklarını ifade

\footnotetext{
38 er-Rûzrâverî, Zeyli Tecaribü'l-Ümem (İbn Miskeveyh'in Tecaribü'l-Ümem'i içinde) c. VII, thk Ebu'l-Kâsım İmâmî, Tahran 2001, s. 276-279; İbnü'l-Esîr, age, IX, s. 103; İbnü'l-Adîm, Buğye, V, s. 2240; Makrîzî, age, I, s. 375; Takkûş, age, s. 290; Yazılıtaş, Fâtımî Devleti'nde Türkler, s. 118.

${ }^{39}$ Makrîzî, Itazu'l-hünefa, I, 2001: s. 375.

${ }^{40}$ er-Rûzrâverî, age, VII, s. 279; İbnü'l-Adîm, Buğye, V, s. 2240; el-Hıyârî, age, s. 60-62; Takkûş, age, s. 290.

${ }^{41}$ er-Rûzrâverî, age, VII, s. 278-282; el-Azîmî, age, s. 321; el-Antâkî, age, s. 290-292; İbnü'l-Cevzî, age, XIV, s. 356-357; İbnü'l-Esîr, age, IX, s. 103-104; Sibt İbnü'l-Cevzî, age, XI, s. 410-411; İbnü'l-Adîm, Buğye, V, s. 2240; el-Hiyârî, age, s. 60-62; Takkûş, age, s. 290-291.

42 er-Rûzrâverî, age, VII, s. 283; el-Antâkî, age, s. 290-292; Cahid Baltacı, "Ebü'l-Fütûh el-Musevî”, DİA, c. X, İstanbul 1994, s. 321
} 
etmektedir $^{43}$. Cerrâhîlerin takip ettiği bu politikadan dolayı Muharrem 404'te (TemmuzAğustos 1013) el-Hâkim Kutbuddevle Ali b. Fellâh’1 Remle'ye sevk etmiş ve daha önce olduğu gibi Cerrâhîler şehri boşaltarak dağlara çekilmişlerdir ${ }^{44}$. Buna rağmen Hassân, Fâtımîlerin Suriye'ye yönelik siyasetlerinde önemli bir rol ifa etmiş, 406'da (1015-1016) Sâlih b. Mirdâs'a karşı Fâtımîlerin Efâmiye valisi Sedîdüddevle Ali ed-Dayf'ın saflarında yer almış ve 407'de (1016-1017) de el-Hâkim'den Haleb'in himayesine yönelik ihtiyatlı davranması gerektiğine dair bir mektup almıştır ${ }^{45}$.

Fâtımî halifesi el-Hâkim 28 Şevvâl 411'de (14 Şubat 1021) vefat etmiş ve yerine de oğlu ezZâhir geçmiştir ${ }^{46}$. Suriye'de yaşanan bu hadiselere kayıtsız kalmayan ez-Zâhir, Muharrem 414'te (Mart-Nisan 1023) Filistin valiliğine Anûştekin ed-Dezberî’yi tayin etmiştir. Bunun üzerine Cerrâhî emîri Hassân da Anûştekin ed-Dezberî ile mücadele edip onu Askalân yakınlarında yenerek tutsak etmiştir ${ }^{47}$. Bundan sonra $415^{\prime}$ te (1024-1025) bir araya gelen Hassân b. el-Müferrec, Sâlih b. Mirdâs ve Sinân b. Ulyân Suriye topraklarını aralarında üleşmişlerdir. Bu anlaşmaya göre Benü'l-Cerrâh'tan Hassân'a Remle'den Misır'a kadar uzanan Filistin toprakları, Halep'ten Ane'ye kadar olan yerler Kilâb Kabilesinden Sâlih b. Mirdâs'a, Dımaşk'ın da Kelb Kabilesinden Sinân b. Ulyân'a bırakılması kararlaştırılmıştır ${ }^{48}$. Suriye'de yaşananlar karşısında bölgeyi yeniden itaat altına almak isteyen Fâtımîler, Anuştekin edDezberî komutasında bir orduyu görevlendirmişlerdir. Bu esnada Hassân hastalanmış ve akıbeti hakkında müphem haberler gelmekteydi. Fırsatı değerlendirmek isteyen Fâtımîler, Anuştekin ed-Dezberî'yi Remle'ye sevk ettiklerinde hastalıktan kurtulan Hassân, 3 bin atlı toplayarak Anuştekin ed-Dezberî’yi Nablus'ta geri çekilmeye zorlamıştır. Hassân, Anuştekin ed-Dezberî ile Remle önlerinde üç gün süren savaşta kardeşi Sâbit'in Anuştekin ed-Dezberî'nin saflarına katılmasından dolayı kardeşinin çadırını yağmalatmıştır. Müteakiben müttefikleri Sinân $b$. Ulyân ve Sâlih b. Mirdâs'tan aldığı yardım ile Filistin'e yönelmiştir. Hassân, bir yandan Bizans'ı bölgeye davet ederken diğer yandan da ez-Zâhir'e muhalif kesimlerin desteğini alarak mücadeleyi lehine çevirmeye çalışmıştır. Bu stratejiler ve Mısır'dan istenen yardımların ulaşamaması üzerine Hassân, 22 Recep 415'te (29 Eylül 1024) geri çekilmiş ve Remle de Hassân'ın hâkimiyeti altına girmiştir. Şehri alan Hassân da dükkânları yağmalamış ve Nasrullah b. Nezzâl'ı da vali tayin ederek Fâtımîlere tabi olduğunu göstermiştir ${ }^{49}$. Bu şekilde Fâtımîler tarafından yapılabilecek olası saldırıları da önlemeyi amaçlamıştır. Bunlardan farklı olarak el-Antâkî, Hassân'ın Fâtımî halifesi ez-Zâhir tarafından zehirletilmek istendiğine dair haberler aldığı için isyan ettiğini kaydetmektedir ${ }^{50}$.

Cerrâhîler ile Fâtımîlerin münasebetlerinin bir ay sonra yani Şaban 415'te (Ekim-Kasım 1024) daha sakin bir şekilde seyretmeye başladığı anlaşılmaktadır. Nitekim Hassân'ın kardeşlerinden biri Mısır'a gelmiş ve kendisine ikramlarda bulunulmuş ve hilat verilmiştir ${ }^{51}$. Müteakiben 1 Ramazan 415'te (6 Kasım 1024) Mısır'da düzenlenen bir törende Benü’l-Cerrâh ve Tayy gibi kabile müntesipleri de yer almış ve benzer şekilde 5 Ramazan (10 Kasım) ve 12

\footnotetext{
43 el-Antâkî, age, s. 290-292.

${ }^{44}$ el-Antâkî, age, s. 305-306; Takkûş, age, s. 291.

45 el-Antâkî, age, s. 325-326; İbnü'l-Adîm, Buğye, V, s. 2240; Takkûş, age, s. 292.

${ }^{46}$ el-Antâkî, age, s. 363; İbnü'l-Esîr, age, IX, s. 244.

${ }^{47}$ İbnü'l-Kalânisî, age, s. 72-73; İbnü’l-Esîr, age, IX, s. 185-186; Makrîzî, age, II, s. 8.

48 İbnü'l-Kalânisî, age, s. 72-73; el-Antâkî, age, s. 389-390; İbnü'l-Esîr, age, IX, s. 185-186; Müsebbihî, Ahbâru Mısr, thk. Eymen Fuad Seyyid-Teyârî Biyânkî, Kahire ts. s. 35-36; Makrîzî, age, II, s. 8; Ali, age, I, s. 222; Takkûş, age, s. 315.

49 el-Azîmî, age, s. 326; el-Antâkî, age, s. 389-393; el-Müsebbihî, age, I, s. 12-13, 47, 52; İbnü'l-Adîm, Zübdetü'lHaleb min Târihi Haleb, c. I, thk. Süheyl Zekkâr, Dımaşk 1997, s. 196-198; Makrîzî, age, II, s. 17, 22-25.

${ }^{50}$ el-Antâkî, age, s. 391

51 el-Müsebbihî, age, I, s. 54; Makrîzî, age, II, s. 26.
} 
Ramazan 415 (17 Kasım 1024) tarihleri arasında Mısır'da Cerrâhîlerden üç kişinin bulunduğu ve söz konusu aile fertlerine hilat, eyerli, gemli ve zırhlı atların verildiği nakledilmektedir ${ }^{52}$. Aynı tarihte Hassân "Fatımîlere itaat ettiğini, Şam'ın durumuna dair halifenin bir endişesinin olmamasını zira kendisinin Filistin'i idare ederek haraç topladığını ve adamlarına dağıttığını, Sinân'ın Dimaşk'l, Sâlih 'in de Halep'i yönettiğini" ifade ederek ez-Zâhir'in endişelenmemesi yönünde bir mektup yazmıştır. Ez-Zâhir bu mektup karşısında Hassân'ın elçisini kovarak herhangi bir cevap vermemiştir ${ }^{53}$. Şüphesiz Suriye ve Filistin'deki gelişmeler ez-Zâhir'in arzu ettiği gibi olmasa da ez-Zâhir, Hassân'ın yönetimini istemeden kabullenmiştir. Hassân'ın üç evladının Mısır'da iskâna icbar edildiği anlaşılmaktadır. Nitekim 27 Ramazan 415'te (2 Aralık 1024) Hassân'ın iki oğlunun Mısır'dan firar etmesi ve diğer oğlunun ise hastalığından dolayı burada kalması Hassân'ın çocuklarının rehine olarak Mısır'da bulunduklarına delalet etmektedir $^{54}$. Çok geçmeden Şevvâl 415'te (Aralık-Ocak 1024-1025) ise Hassân'ın Mısır'da mukim Beni Kurre'ye bir elçi göndererek yardım talebinde bulunduğu ve elçinin Fâtımîler tarafından yakalanarak hapsedildiği görülmektedir ${ }^{55}$. 415 (Zilkade/Ocak-Şubat 1025) yılının sonlarında ise Hassân, Fâtımî komutanı ed-Dezberî ve Feth ile yaptığ 1 savaşta iki oğlunu kaybederek ağır bir yenilgi almıştır ${ }^{56}$.

Kelb Kabilesi lideri Sinân b. Ulyân'nn Cemaziyülahir 419'da (Haziran-Temmuz 1028) vefat ederek yerine kardeșinin oğlu Râfi' b. Ebi'l-Leyl b. Ulyân'ın geçmesi Tayy, Kelb ve Kilâb kabileleri arasında oluşturulan ittifakı da sona erdirmiştir ${ }^{57}$. Bu gelişmenin yanı sıra Cerrâhî lideri Hassân da hasat mevsimlerinde yağma ve saldırılarda bulunurak kış mevsiminde de çöllere çekilmek suretiyle bölgenin nizamını bozmaktayd ${ }^{58}$. Bunun üzerine Fâtımîler, Anuştekin ed-Dezberî̀yi Hassân'ın sebep olduğu kargaşayı sonlandırmak amacıyla Filistin'e göndermişlerdir. Daha önce Hassân ile müttefik olan Kelb Kabilesinin yeni lideri Râfi' b. Ebi'l-Leyl ise Fâtımîlerin saflarında yer almaktaydı. Halep Mirdâsî emîri Sâlih b. Mirdâs da yaptığı anlaşmaya inkıyat ederek Hassân'a yardım etmek gayesiyle harekete geçmiştir. Taraflar Ürdün Nehri üzerinde Taberiyye'de el-Ukhuvâne adlı yerde 25 Rebiyülahir 420'de (13 Mayıs 1029) karşılaşmışlardır. Savaş esnasında Tayy ve Kilâb kabilelerinin oluşturduğu ittifak bloğu yenilmiş ve Sâlih b. Mirdâs da yaralanarak tutsak alınmıştır. Salih, Râfî b. Ebi'l-Leyl tarafından öldürülmüş ve kesik başı da Anuştekin ed-Dezberî’ye gönderilmiştir. Söz konusu bu hezimetten sonra Hassân da mutat olduğu üzere dağlara çekilmiştir. Fâtımîlerin bu zaferi ile birlikte Benü'l-Cerrâh'ın Bilâdü'ș-Șâm'daki gücü kırılmıș ve Kilâb Kabilesinin Ba'lebek, Humus, Saydâ, Refeniyye ve Hısnı İbn Akkâr gibi şehirlerdeki otoritesi de sona ermiştis ${ }^{59}$. Böylece Fâtımîlerin Biladü'ş-Şâm hâkimiyeti önündeki önemli engellerden biri de ortadan kalkmışırır.

El-Ukhuvâne mağlubiyetinden sonra dağlara çekilen Hassân ise daha sonra Bizans'a sığınmıştır. Hassân, Recep 421'de (Temmuz-Ağustos 1030) Bizans'ın Suriye taarruzu esnasında Bizans saflarında bulunmuştur ${ }^{60}$. Hassân, Bizans'tan aldığı destekle Efâmiye'ye saldırınca Fâtımîler, Anuştekin ed-Dezberî'yi Hassân'ı cezalandırmak için Bilâdü’ş-Şâm’a

\footnotetext{
${ }^{52}$ el-Müsebbihî, age, I, s. 61, 63.

53 el-Müsebbihî, age, I, s. 64-65; Makrîzî, II, s. 30; Takkûş, 2007, s. 315-316.

${ }^{54}$ el-Müsebbihî, age, I, s. 65.

55 el-Müsebbihî, age, I, s. 68.

${ }^{56}$ el-Müsebbihî, age, I, s. 76, 83, 89; Makrîzî, age, II, s. 34, 35, 38.

${ }^{57}$ el-Azîmî, age, s. 328; el-Antâkî, age, s. 410-411; Takkûş, age, s. 316.

58 el-Antâkî, age, s. 410-411.

59 el-Azîmî, age, s. 329; el-Antâkî, age, s. 411-412; İbnü'l-Cevzî, age, XV, s. 201-202;íbnü'l-Esîr, age, IX, s. 285; Sıbt İbnü'l-Cevzî, age, XII, s. 134-135; İbnü'l-Adîm, Zübde, I, s. 200-201; Ali, age, I, s. 222-223; el-Hıyârî, age, s. 65; Takkûş, age, s. 316; Yazılıtaş, Fâtımî Devleti'nde Türkler, s. 134-137.

${ }^{60}$ el-Antâkî, age, s. 413-417; Ali, age, I, s. 223.
} 
yönlendirmişlerdir. Fâtımî birlikleri Kastûn'da Benü'l-Cerrâh'ın obasını yağmalayarak aldıkları esirler ile geri dönmüşlerdir ${ }^{61}$. Bunun üzerine Hassân kabilesinden 20 bin kişi ile Filistin’i terk edip Antakya'nın güneydoğusundaki Bizans topraklarına yerleşmiştir ${ }^{62}$. Bunun yanı sıra Hassân'ın oğlu Allâkâ da 422'de (1031-1031) Bizans imparatoru tarafından patrik (batrik: patricuis) tayin edilmiştir ${ }^{63}$. Bizans ile ittifakını devam ettiren Hassân, Recep 427'de (NisanMayıs 1036) Urfa'nın Numeyrîler ve Mervânî Emîri Nasruddevle tarafından kuşatılması esnasında da şehirdeki Rumların yardımına gitmekten de imtina etmemiştir ${ }^{64}$.

Fâtımî komutanı Anuştekin ed-Dezberî, Şaban 429'da Bizans ile yapmış olduğu anlaşmadan sonra Halep'e yürüdüğünde yanında bulunanlardan biri de Alân veya Allâkâ b. Hassân b. elCerrâh idi ${ }^{65}$. Benü'l-Cerrâh'ın lideri Hassân, Anuştekin ed-Dezberî'nin Cemaziyülevvel 433 'te (Aralık 1041-Ocak 1042) vefat etmesinden sonra Rum diyarından dönmüş ve Filistin'de yeniden isyan bayrağını açmıştır ${ }^{66}$. Hassân'ın adını mezkûr tarihte vuku bulan isyandan sonra kaynaklarda takip edememekteyiz. Ancak bu durum Benü'l-Cerrâh'ın Filistin ve çevresindeki rolünün tamamen bittiği anlamına gelmemektedir. Söz konusu tarihten sonra da Benü'lCerrâh'ın intisap ettiği Tayy Kabilesi Fâtımîlerin Bilâdü'ş-Şâm'daki eylemlerinde önemli roller ifa etmişlerdir. Fâtımîlerin Dımaşk valisi Rıfk el-Hâdim el-Mustansırî'nin 442'de (1050) Halep'e yapmış olduğu saldırıda Rıfk el-Hâdim'in hezimete uğramasında Tayy ve Kelb kabilelerinin katkıları oldukça büyüktür ${ }^{67}$.

Hassân'dan sonra Tayy Kabilesi Fâtımîler ile ittifak halinde hareket etmiştir. Fâtımî halifesi el-Mustansır, Şaban 443'te (Aralık 1052) Mısır'da isyan eden Benî Kurre Kabilesini itaat altına almak için Tayy, Kelb ve diğer bazı Arap kabilelerin yardımına müracaat etmek zorunda kalmıştı́ $^{68}$. Fâtımîler 452'de (1060-1061) 15 bin kişilik bir süvari birliği ile Halep Mirdâsî emiri Mahmud'un üzerine Nâsıruddevle Ebu Ali el-Hüseyin'i gönderdiklerinde Tayy ve Kelb kabileleri Fâtımîlerin saflarında bulunmuşlardır ${ }^{69}$. Ayrıntısı bilinmemekle beraber Nâsıruddevle, mezkûr tarihte Misır' da Hizânetü'l-bunûd adlı yerde mevkuf bulunan Humyed b. Mahmud b. el-Cerrâh ve Hâzim b. Ali b. el-Cerrâh'ın serbest bırakılması için tavassutta bulunmuştur $^{70}$.

Bizans birlikleri 462'de (1069-1070) Menbic şehrini yağmaladıklarında Tayy Kabilesinin liderleri Hâzim b. Ali b. el-Cerrâh ve Bedr b. Hâzim de Mirdâsî Emîri Mahmud ile birlikte Bizans'a karşı savaşmışlard ${ }^{71}$. Benü'l-Cerrâh ailesine ait son kayıt ise 469 (1076-1077) yılına ait olup, mezkûr tarihte Kahire önlerinde Atsız ile birlikte hareket eden Bedr b. Hâzim b. Ali b. el-Cerrâh, savaş esnasında Fâtımîlerin saflarına katılarak savaşın sonucunda belirleyici bir rol oynamıştır $^{72}$. Tayy Kabilesinin fonksiyonunun söz konusu hadiseden sonra da devam ettiği ve Şam bölgesindeki hâkimiyet mücadelelerinde yardımlarına başvurulan güçlerden biri olmaya devam ettiği gözükmektedir. 476’da (1083-1084) Benî Ukayl emiri Şerefüddevle Müslim b.

\footnotetext{
${ }^{61}$ el-Antâkî, age, s. 430-432; İbnü'l-Esîr, age, IX, s. 321-322; Sıbt İbnü'l-Cevzî, age, XII, s. 153; Makrîzî, age, II, s. 43.

${ }^{62}$ Takkûş, age, s. 317.

63 el-Antâkî, age, s. 424-425.

${ }^{64}$ İbnü'l-Esîr, age, IX, s. 342-343.

${ }^{65}$ İbnü'l-Kalânisî, age, s. 74; İbnü'l-Adîm, Zübde, I, s. 213-214.

${ }^{66}$ İbnü'l-Esîr, age, IX, s. 383; Sibt İbnü'l-Cevzî, age, XII, s. 213.

${ }^{67}$ İbnü'l-Adîm, Zübde, I, s. 226.

${ }^{68}$ İbnü'l-Esîr, age, IX, s. 438-439.

${ }^{69}$ İbnü'l-Adîm, Zübde, I, s. 237; Sibt İbnü'l-Cevzî, age, XII, s. 343; el-Hiyârî, age, s. 67-68.

${ }^{70}$ İbnü'l-Kalânisî, age, s. 93; el-Azîmî, age, s. 346; Makrîzî, age, II, s. 110.

${ }^{71}$ İbnü'l-Esîr, age, X, s. 68; Sibt İbnü'l-Cevzî, age, XII, s. 468.

${ }^{72}$ Makrîzî, age, II, s. 110.
} 
Kureyş'e hizmet etmişlerdir ${ }^{73}$. Son olarak da 501'de (1107-1108) Benü'l-Cerrâh'tan Ebu İmrân Fazl b. Rebi b. Hâzim b. el-Cerrâh, Selçuklu sultanının huzuruna çıkmak için Bağdat'a gelmiştir $^{74}$. XII. yüzyılda Benü'l-Cerrâh ahfadından Fazl, Serat ve Belkâ bölgesinde yeni bir siyasî güç oluşturmuş ve Haçlılara karşı yapılan savaşlarda da Müslüman ordusu içinde milis unsur olarak bulunmuştur ${ }^{75}$. Tayy Kabilesinin Şam bölgesindeki faaliyetlerinin Eyyübî ve Memlûk devletleri döneminde de devam ettiği anlaşılmaktadır ${ }^{76}$. Benü'l-Cerrâh, Fâtımîler döneminde Suriye ve Filistin'de yaşanan hadiselerde aktif bir şekilde yer almış ve belirleyici olmuştur.

\section{Sonuç}

Müslümanların Arap Yarımadası dışına doğru icra ettikleri fetih hareketlerinden sonra Bilâdü'ş-Şam, Filistin ve Ürdün gibi coğrafyalara Arap fatihler yerleşmeye başlamışlardır. Söz konusu bu göç hareketleri bölgenin siyasî, idarî, demografik ve dinî yapısında da belirgin değişiklikler meydana getirmiştir. Fetihlerin ilk dönemlerinde göç eden Arap kabileler merkezî yönetime inkıyat ederek uyum sağlarken, onuncu asırdan sonra Abbâsîlerin siyasî erkleri zayıflayınca Hamdânî, Numeyrî, Mirdâsî, Ukaylî gibi kabileler bulundukları şehirlerde birer emirlik kurmaya muvaffak olmuşlardır. Bunların dışındaki diğer kabileler de bağımsızlık için gayret göstermelerine rağmen siyasî, askerî ve coğrafî konjonktürden dolayı bunu gerçekleştirememişlerdir. Filistin'e yerleșen daha sonra da Remle merkez olmak üzere onuncu asırda faaliyetlerine hız veren ve Benî Tayy'ın bir kolu olan Benü'l-Cerrâh da bağımsızlık için mücadele etmiş fakat bunu gerçekleştirememiş̧ir. Mezkur kabileler gibi bağımsız bir siyasîidarî yap1 oluşturamamaları Fâtımîler ve Bizans gibi iki büyük gücün mücadelelerinin merkezinde yer almalarından kaynaklanmaktadır. Bu mücadeleler muvacehesinde Benü'lCerrâh'ın yağmalardan ve zaman zaman anlaşmalar dolayısıyla aldıkları gelirlerden faydalanmayı şiar edindikleri anlaşılmaktadır. Siyasî açıdan dikkate değer en büyük girişimleri de 403'te (1012) Mekke şerifi Ebi'l-Fütûh'u Remle'ye davet ederek bağımsız bir halife tayin etmeleri olmuştur. Ancak Fâtımîler mutat olduğu üzere, bu girişimi Cerrâhîlere maddî bazı imkânlar sunarak bertaraf etmeyi başarmışlardır. İstikrarlı ve daimî bir yapı oluşturamamalarının diğer bir sebebi de aynı anda birden fazla lider tarafından yönetilmiş olmalarında aranmalıdır. Fâtımîlerin Bilâdü'ş-Şâm'a doğru yayılmaları esnasında Kelb, Kilâb ve Tayy gibi kabilelerin muhalif bir hareket oluşturmaları bölgenin bundan sonraki yapısını da belirgin bir şekilde değiştirmiştir. Şüphesiz Kelb, Kilâb ve Tayy kabileleri 420'de (1029) elUkhuvâne'de Fâtımîlere yenilince Cerrâhîler Bizans'a sığınmış ve sonrasında da Antakya civarına göç ederek bir süre burada ikamet etmek zorunda kalmışlardır. Bu sırada Bizans'ın Bilâdü'ş-Şam üzerine icra ettiği bazı saldırılara da iştirak etmişlerdir. 433'te (1041-1042) Cerrâhî lideri Hassân ülkesine dönmesine rağmen bu tarihten sonra adına tesadüf edilememesi onların siyasî etkilerinin zayıfladığını göstermektedir. Sonuç olarak Cerrâhîler otoriter ve güçlü liderler ile güçlerini muhafaza etmiş, bu vasıflara sahip liderlerin olmadığı durumlarda da pasif kalmışlardır. Ancak yine de Haçlı seferleri esnasında milis güçler ile birlikte Haçlılara karşı mücadele etmeleri ve Eyyûbîler ve Memlûkler döneminde faaliyetlerini sürdürmeleri bölgenin siyasî ve askerî yapısında etkilerinin devam ettiğini göstermektedir.

\section{Kaynaklar}

ALİ, Muhammed Kürd, Hittatu'ş-Şâm, c. I, Kahire 2007.

\footnotetext{
73 İbnü'l-Adîm, Zübde, I, s. 309.

${ }^{74}$ Canard, age, s. 484.

${ }^{75}$ Hureysât, age, s. 416

${ }^{76}$ el-Hiyârî, age, s. 70.
} 
APAK, Âdem, "Tay (Benî Tay)", Türkiye Diyanet Vakfi İslam Ansiklopedisi (DİA), c. XL, İstanbul 2011, s. 187.

BALTACI, Cahid, “Ebü'l-Fütûh el-Musevî”, Türkiye Diyanet Vakfi İslam Ansiklopedisi (DIA), c. X, İstanbul 1994, s. 321.

BOSWORTH, Clifford Edmund, Doğuştan Günümüze İslâm Devletleri Tarihi, çev. Hande Canl1, İstanbul 2005.

CANARD, Marius, "Djarrahids", The Encyclopaedia of Islam (EI), II, Leiden 1991, s. 482-485.

ÇELİK, Aydın, "Fatımîler Devletinde Bir Türk Komutan: Alptekin", Firat Üniversitesi Sosyal Bilimler Dergisi, c. 12, sayı 1, Elazı̆̆ 2002, s. 283-296.

EBÛ ŞEMÂLE, Şerif Emîn Muhammed, Filistîn Tahte'l-Hükmi'l-Abbâsî el-Mübâşir (h. 132264/750-878), (el-Câmi'atu'l-İslâmiyye), Gazze 2011.

ED-DEBBÂĞ, Mustafa Murad, Bilâdunâ Filistîn, c. 4/2. Kısım, Kefer Kara’ 1991.

EKİNCİ, Abdullah, Ortadoğu'da Marjinal Bir Hareket: Karmatîler (Ortadoğu'da İlk Sosyalist Yapılanma), Ankara 2005.

EL-ANTÂKÎ, Tarihu'l-Antâkî, thk. Ömer Abdusselam Tedmürî, Trablus 1990.

EL-AZÎMÎ, Tarihu Haleb, thk. İbrahim Za'rûr, Dımaşk 1984.

EL-EZDÎ, Ali b. Zâfir, Ahâru'd-devleti'l-Hamdâniyye bi'l-Mevsıl ve Haleb ve Diyâr-ı Bekr ve's-Suğûr, thk. Temîme er-Ravvâf, Beyrut 1985.

EL-HIYÂRÎ, Mustafa Ali Mustafa, el-Imâretü't-Tâ'iyye fî Bilâdi'ş-Şâm fî̀l-karneyn es-sâlis aşer ve'r-râbî' aşer el-milâdeyn, Beyrut 1969.

ER-RÛZRÂVERÎ, Zeyli Tecaribü'l-Ümem (İbn Miskeveyh'in Tecaribü'l-Ümem'i içinde) c. VII, thk Ebu'l-Kâsım İmâmî, Tahran 2001.

HUREYSÂT, Muhammed Abdulkadir, "Cerrâhîler", Türkiye Diyanet Vakfi İslam Ansiklopedisi (DIA), c. VII, s. 415-416

İBN MISKEVEYH, Tecâribü'l-Ümem ve Te'akubi'l-Himem, c. VI, thk. Ebu'l-Kâsım İmâmî, Tahran 2000; Türkçe trc. İbn Miskeveyh, Tecâribü'l-Ümem, trc. Kıvameddin Burslan, Ankara 2016.

İBNÜ'L-ADÎM, Buğyetu't-taleb fí tarihi Haleb, c. V, thk. Süheyl Zekkâr, Beyrut ts.

İBNÜ'L-ADÎM, Zübdetü'l-Haleb min Târihi Haleb, c. I, thk. Süheyl Zekkâr, Dımaşk 1997.

İBNÜ'L-CEVZÎ, el-Muntazam fí Tarihi'l-Mülûk ve'l-Ümem, c. XIV-XV, thk. Muhammed Abdulkadir Ata-Mustafa Abdulkadir Ata, Beyrut 2012.

İBNÜ’L-ESÎR, el-Kâmil fì't-Tarih, c. VIII-IX-X, çev. Ahmet Ağırakça-Abdülkerim Özaydın, İstanbul 1991.

İBNÜ'L-KALÂNİSî, Zeylü Târîhi Dımaşk, thk. H. F. Amedroz Beyrut 1908.

MAKRÎZî, İtti'azü'l-hünefâ bi-ahbâri'l-e'immeti'l-Fâttmîyyin el-Hulefâ, c. I-II, thk. Muhammed Abdulkadir Ahmed Ata, Beyrut 2001.

MÜSEBBi̇HÎ, Ahbâru Mısr, thk. Eymen Fuad Seyyid-Teyârî Biyânkî, Kahire ts.

.


ÖZ, Mustafa, "Hâkim-Biemrillah", Türkiye Diyanet Vakfi İslam Ansiklopedisi (DİA), c. XV, İstanbul 1997, s. 199-201.

ÖZKAN, Halit, "Vezîr el-Mağrib̂̂” Türkiye Diyanet Vakfi İslam Ansiklopedisi (DİA), c. XLIII, İstanbul 2013, s. 92-94.

SIBT İBNÜ'L-CEVZÎ, Mirât'z-Zamân fî Tarîhi'l-'Ayân, c. XI-XII, thk. Kamil Selman elCebûrî, Dâru'l-Kutubi'l-İlmiyye, Beyrut 2013.

TAKKÛŞ, Muhammed Süheyl, Târihu'l-Fâtımiyyin fì Şimâli Ifrikiyye ve Mısır ve Bilâdi'şŞâm, Beyrut 2007

YÂKÛT EL-HAMEVÎ, Mu'cemu'l-Buldân, I, Beyrut 2010, s. 94-98.

YAZILITAŞ, Nihat, Fâtımî Devleti'nde Türkler, Ankara 2009.

YAZILITAŞ, Nihat, Fâtımî Devleti Tarihi, İstanbul 2010. 